\title{
Demystificatie van pensioenficties
}

Citation for published version (APA):

Broeders, D. (2017). Demystificatie van pensioenficties. Maastricht University. https://doi.org/10.26481/spe.20170310db

Document status and date:

Published: 10/03/2017

DOI:

10.26481/spe.20170310db

Document Version:

Publisher's PDF, also known as Version of record

\section{Please check the document version of this publication:}

- A submitted manuscript is the version of the article upon submission and before peer-review. There can be important differences between the submitted version and the official published version of record.

People interested in the research are advised to contact the author for the final version of the publication, or visit the DOI to the publisher's website.

- The final author version and the galley proof are versions of the publication after peer review.

- The final published version features the final layout of the paper including the volume, issue and page numbers.

Link to publication

\footnotetext{
General rights rights.

- You may freely distribute the URL identifying the publication in the public portal. please follow below link for the End User Agreement:

www.umlib.nl/taverne-license

Take down policy

If you believe that this document breaches copyright please contact us at:

repository@maastrichtuniversity.nl

providing details and we will investigate your claim.
}

Copyright and moral rights for the publications made accessible in the public portal are retained by the authors and/or other copyright owners and it is a condition of accessing publications that users recognise and abide by the legal requirements associated with these

- Users may download and print one copy of any publication from the public portal for the purpose of private study or research.

- You may not further distribute the material or use it for any profit-making activity or commercial gain

If the publication is distributed under the terms of Article $25 \mathrm{fa}$ of the Dutch Copyright Act, indicated by the "Taverne" license above, 


\section{Maastricht University}

\section{Prof.dr. Dirk Broeders}

School of Business and Economics

\section{Demystificatie van pensioenficties}

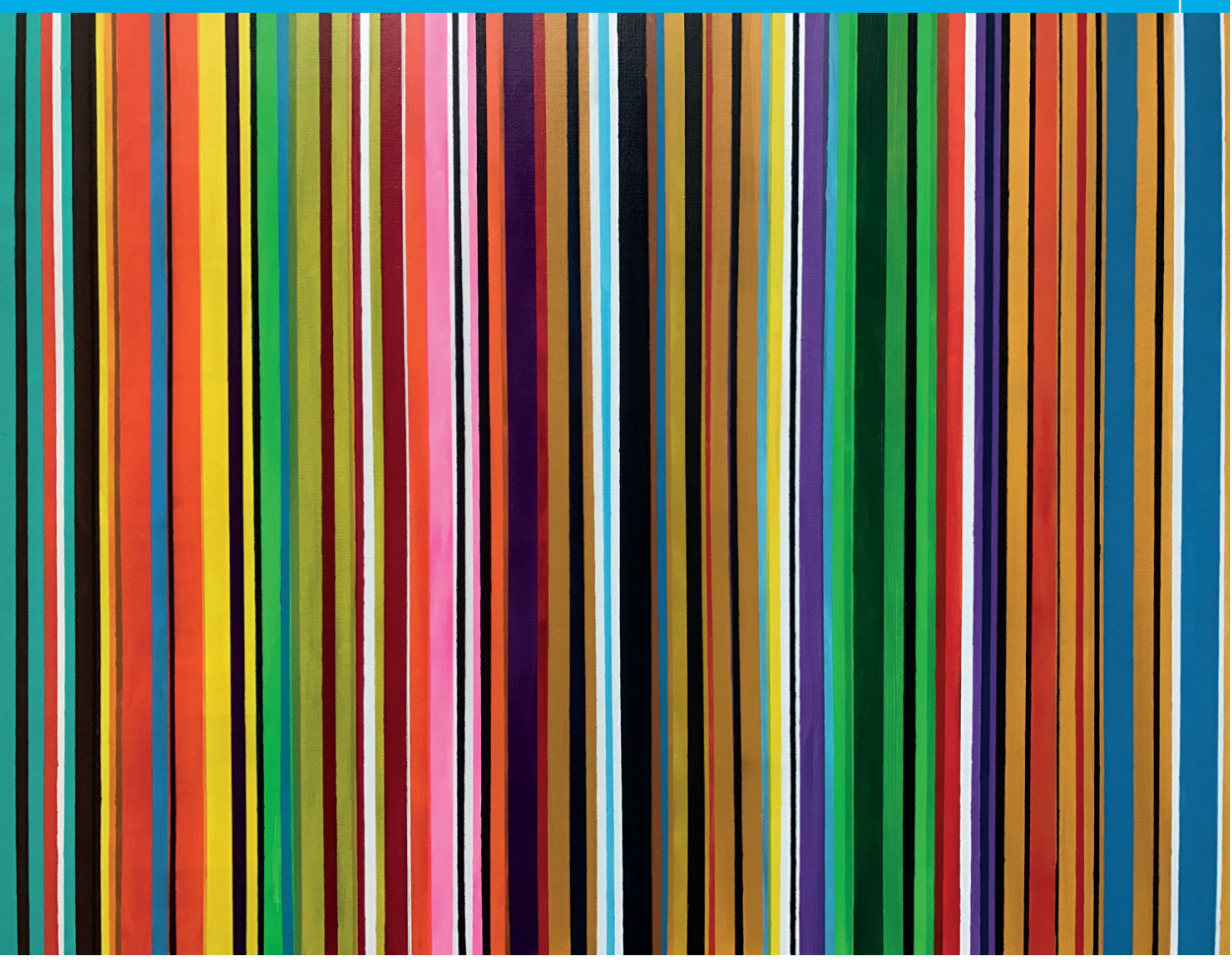


Demystificatie van pensioenficties 


\section{Colofon}

Design: Canon Business Services, Maastricht

Ontwerp omslag: Iwona Sroczynska

ISBN: 978-90-5681-471-7

NUR: 793

Alle rechten voorbehouden. Niets uit deze uitgave mag worden verveelvoudigd, opgeslagen in een geautomatiseerd gegevensbestand of openbaar gemaakt worden, zonder voorafgaande schriftelijke toestemming van de auteur of uitgever. 


\section{Demystificatie van pensioenficties}

\section{Oratie}

In verkorte vorm uitgesproken bij de aanvaarding van het ambt van hoogleraar "Pension Finance and Regulation" aan de School of Business and Economics van de Universiteit Maastricht.

Op 10 maart 2017

Door prof.dr. Dirk Broeders 
Demystificatie van pensioenficties 


\section{Demystificatie van pensioenficties}

Mevrouw de Rector Magnificus, geacht College van Decanen, geachte collega's, zeer gewaardeerde toehoorders, lieve vriendin, kinderen en familie.

De leerstoel die ik vandaag met veel genoegen aanvaard heeft als titel 'pension finance and regulation'. De essentie van pensioenregulering is in mijn visie eenvoudig en zelfs in een zin samen te vatten. Pensioenregulering dient gebaseerd te zijn op algemeen aanvaarde economischeenactuariële principes. Dus op beproefdewetenschappelijke inzichten. Over pensioenregulering is daarom eigenlijk weinig discussie te verwachten. Niets is minder waar. Regulering van pensioenfondsen is een even boeiend als veelbesproken onderwerp. Het krijgt veel aandacht van internationale en nationale instituties bevoegd met het uitvaardigen van regels. Academici, politici, pensioenfondsbestuurders en professionals buigen zich hierover. Veel individuen uiten hun mening over pensioenregulering. Het is dan ook niet verwonderlijk dat die meningen op Twitter voorbij komen.

\section{Het fenomeen van de 'rekenrentetweet' en machine learning}

Pensioenregulering op Twitter

Om de meningen over pensioenregulering in kaart te brengen maak ik om te beginnen een analyse van het meest besproken thema als het om pensioenregulering gaat. $U$ raadt het al. De rekenrente. Laten we eens kijken naar de twitteractiviteit over dit onderwerp. Sinds 2009 zijn 21.374 unieke tweets geregistreerd met daarin het woord rekenrente of 'hashtag' rekenrente. De retweets niet meegerekend. De GPS-locaties van deze rekenrentetweets ziet u op de landkaart in Figuur 1. 
Figuur 1: GPS-locaties rekenrentetweets

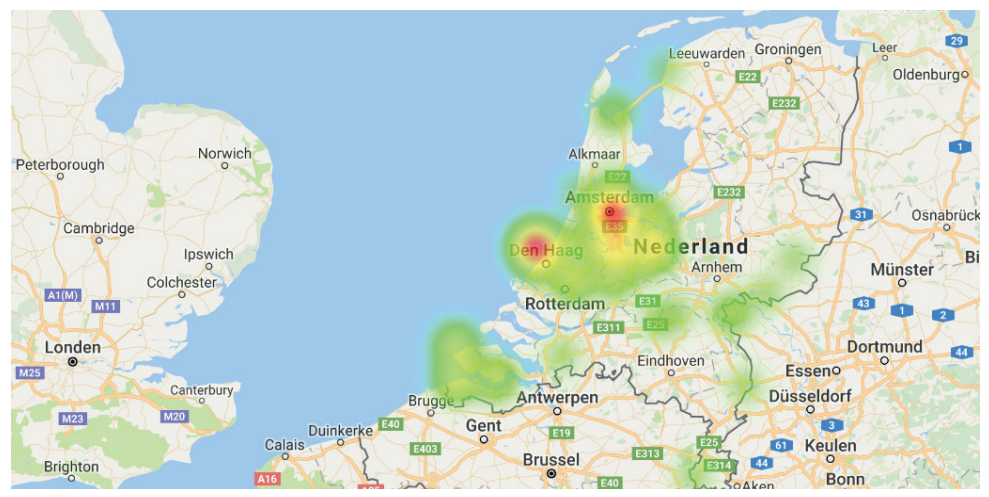

Bron: Twitter, Coosto, De Nederlandsche Bank.

Per week tellen we gemiddeld 65 tweets. Met zo nu en dan forse uitschieters in het aantal rekenrentetweets. Zoals bij de invoering van de Ultimate Forward Rate voor pensioenfondsen in de zomer van 2012. En bij de aanpassing van deze Ultimate Forward Rate in de zomer van 2015. Later in deze rede ga ik dieper in op de Ultimate Forward Rate. Voor nu constateer ik dat het woord rekenrentetweet vermelding verdient in de Dikke van Dale. Dit aangezien twitteren over de rekenrente een heus fenomeen is. Zo waar een leuke bijvangst van pensioenregulering.

Naast het aantal tweets per GPS-locatie is het natuurlijk vooral interessant om te kijken naar de twitteraar en de inhoud van tweets. Mannen nemen 63 procent van alle rekenrentetweets voor hun rekening. De groep twitteraars uit de politieke arena daarentegen is verhoudingsgewijs het kleinst. Met behulp van woordanalyse is het mogelijk om het sentiment van een tweet te bepalen. En wel in een van de volgende drie smaken: positief, neutraal of negatief. In Tabel 1 ziet $u$ dit sentiment. De meerderheid van de tweets is neutraal. Wel zijn zowel mannen als vrouwen met een sterke mening iets meer negatief dan positief als het om de rekenrente gaat. Opvallend is dat de uitgesproken politieke tweets over de rekenrente min of meer in evenwicht zijn. 
Tabel 1: Sentiment 'rekenrentetweets'

\begin{tabular}{|l|l|l|l|l|}
\hline Rekenrente & activiteit & positief & negatief & neutraal \\
\hline Man & $63 \%$ & $10 \%$ & $14 \%$ & $76 \%$ \\
\hline Vrouw & $10 \%$ & $9 \%$ & $14 \%$ & $77 \%$ \\
\hline Politiek & $4 \%$ & $8 \%$ & $9 \%$ & $83 \%$ \\
\hline Overig & $24 \%$ & $4 \%$ & $7 \%$ & $89 \%$ \\
\hline
\end{tabular}

Bron: Twitter, Coosto, De Nederlandsche Bank.

Ik vervolg met eenzelfde analyse over een ander markant thema in pensioenregulering. Het gaat hier om intergenerationele risicodeling (IGR). Dit betreft het delen van risico's met generaties die nog niet in het pensioenfonds zitten. De twitteractiviteit hierover is aanzienlijk minder. Dit is niet verwonderlijk want na '\#intergenerationelerisicodeling' heb je nog maar 109 tekens over om een punt te maken. De landkaart in Figuur 2 laat een opvallend beeld zien. Amsterdam en Den Haag zijn twee duidelijke epicentra. Dit is opmerkelijk omdat de communicatie tussen De Nederlandsche Bank en het Ministerie van Sociale Zaken over dit onderwerp niet via twitter verloopt. Verder twitteren zowel mannen als vrouwen met een uitgesproken mening doorgaans wat positiever over dit thema. Dit is in het geval van vrouwen niet gek, zij profiteren relatief meer van risicodeling vanwege de doorsneesystematiek. Politieke partijen lijken daarentegen dit onderwerp te mijden op Twitter. Dit is wel opmerkelijk want de balans van de overheid wordt met uitstek gebruikt voor risicodeling met toekomstige generaties.

Figuur 2: GPS-locaties tweets intergenerationele risicodeling

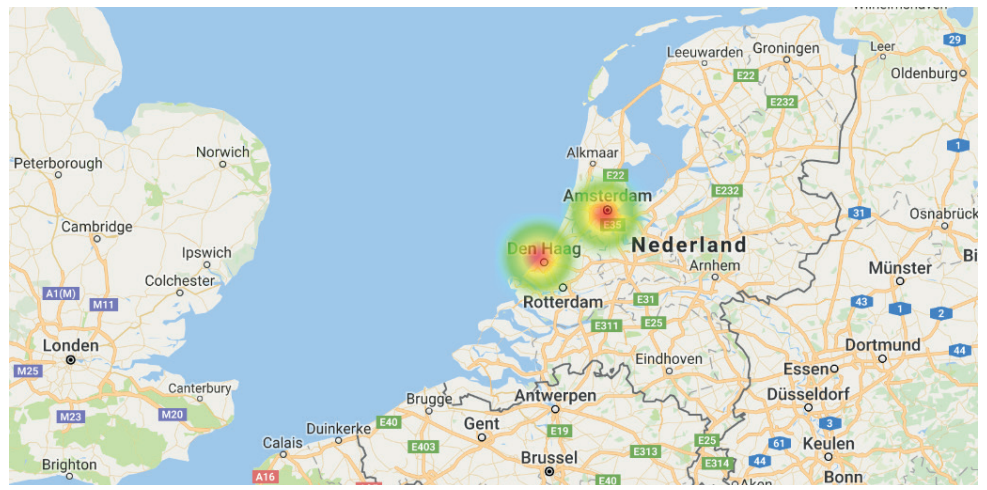

Bron: Twitter, Coosto, De Nederlandsche Bank. 
Tabel 2: Sentiment tweets intergenerationele risicodeling

\begin{tabular}{|l|l|l|l|l|}
\hline IGR & activiteit & positief & negatief & neutraal \\
\hline Man & $61 \%$ & $9 \%$ & $4 \%$ & $87 \%$ \\
\hline Vrouw & $13 \%$ & $14 \%$ & $3 \%$ & $83 \%$ \\
\hline Politiek & - & - & - & - \\
\hline Overig & $26 \%$ & $8 \%$ & $3 \%$ & $89 \%$ \\
\hline
\end{tabular}

Bron: Twitter, Coosto, De Nederlandsche Bank.

Als laatste kijk ik naar pensioenkortingen. Of afstempelen. De twitteractiviteit op landelijk niveau is wederom serieus. $U$ ziet in Figuur 3 dat het land is bedekt met een deken van tweets over dit thema. Meer dan 17.000 afstempeltweets in acht jaar tijd. Vrouwen zijn iets positiever over afstempelen. De politiek laat zich, om haar moverende redenen, wat negatiever via twitter uit over dit thema.

Figuur 3: GPS-locaties tweets pensioenkortingen

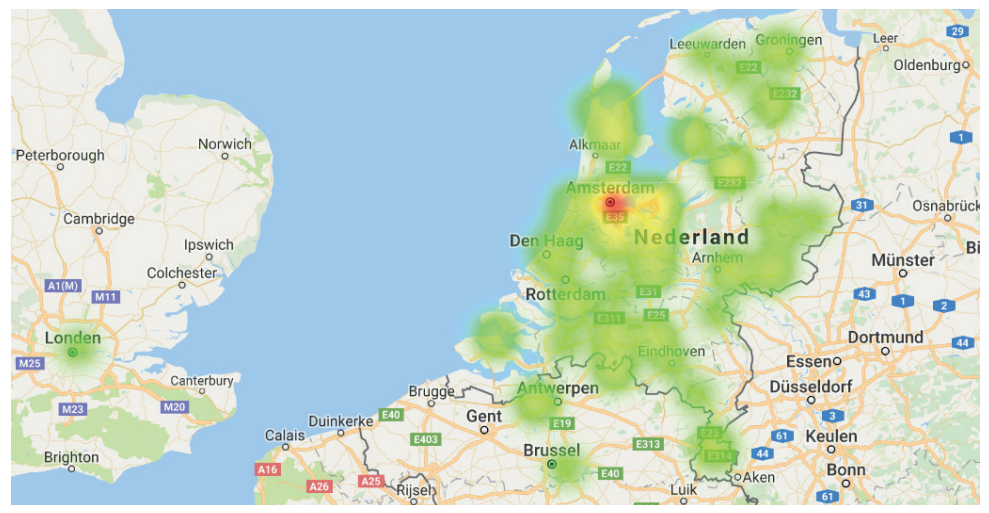

Bron: Twitter, Coosto, De Nederlandsche Bank.

Tabel 3: Sentiment tweets pensioenkortingen

\begin{tabular}{|l|l|l|l|l|}
\hline Afstempelen & activiteit & positief & negatief & neutraal \\
\hline Man & $39 \%$ & $10 \%$ & $13 \%$ & $77 \%$ \\
\hline Vrouw & $12 \%$ & $14 \%$ & $11 \%$ & $75 \%$ \\
\hline Politiek & $3 \%$ & $8 \%$ & $27 \%$ & $65 \%$ \\
\hline Overig & $47 \%$ & $9 \%$ & $7 \%$ & $84 \%$ \\
\hline
\end{tabular}

Bron: Twitter, Coosto, De Nederlandsche Bank. 
Een wedstrijd tussen Academic en Industry Papers

Ook in kranten blijft pensioenregulering niet onbesproken. Daarom neem ik $u$ nu mee in een analyse van alle opiniërende artikelen in het Financieele Dagblad waarin het woord rekenrente voorkomt. Over de afgelopen 10 jaar betreft dit niet minder dan 204 artikelen. Om de inhoud van deze artikelen te classificeren ga ik gebruik maken van 'machine learning. Om de machine te trainen voed ik deze met kennis verzameld in publicaties van Netspar. Hiervoor gebruik ik een tiental Netspar Academic Papers en een tiental Netspar Industry Papers. Voor enkele Academic Papers is het nodig deze eerst door een computerprogramma te laten vertalen van Engels naar Nederlands. Vervolgens vraag ik de machine welke papers het beste worden gelezen door de schrijvers van FD artikelen over de rekenrente. De Academic of de Industry Papers?

In Figuur 4 ziet $u$ het vonnis van de machine. Van de 204 artikelen sluiten er 72 aan bij de Academic Papers. En 132 sluiten meer aan bij de Industry Papers. Correspondentie over deze uitslag is niet mogelijk. De machine kan niet aangeven hoe het tot deze uitslag komt. Dit is een wezenlijk kenmerk van kunstmatige intelligentie. Nu is dit natuurlijk ook geen serieuze wedstrijd. Beide Netspar reeksen zijn uitermate belangrijk en hebben elk hun eigen doel. Het punt dat ik wil maken is dat kunstmatige intelligentie en 'data science' hun opmars maken in de financiële wereld. Dit is voor pensioenfondsen, wetgever en toezichthouders een belangrijke ontwikkeling. Een van de interessante vragen is of we kunnen leven met 'the computer says no'. Dus het feit dat uitkomsten van complexe beslisalgoritmes niet repliceerbaar zijn zoals in het voorbeeld van de Netspar wedstrijd (Wachter, Brent Mittelstadt en Luciano, 2016).

Figuur 4: Uitslag FD artikelen en Netspar papers

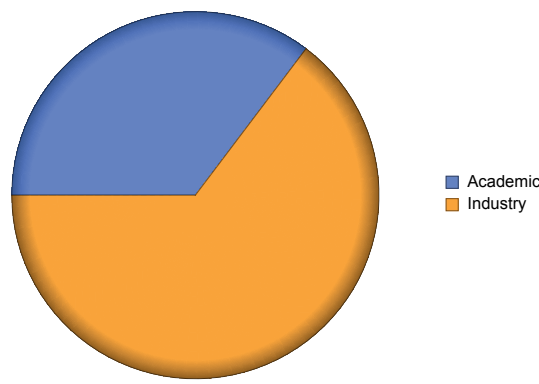

Bron: Financieele Dagblad en Netspar. Het algoritme 'Classify' uit Mathematica is gebruikt als machine learning tool. 
Het onderzoek onder de vleugels van Netspar is een waardevol bezit voor de pensioenwereld. Het is goed om op twitter, andere social media en in de kranten maatschappelijke betrokkenheid te zien bij een belangrijk thema als pensioen. Tegelijkertijd zijn de financiering van pensioen en de regulering van pensioenfondsen ingewikkelde onderwerpen die met mystiek zijn omgeven. Om die mystiek enigszins weg te nemen wil ik in deze rede de volgende onderwerpen aansnijden. Om te beginnen bespreek ik enkele pensioenficties. Dit zijn, zo u wilt, misverstanden over pensioen die soms leven. Daarna loop ik enkele algemeen aanvaarde economische en actuariële principes langs die een centrale rol spelen in pensioenregulering. Vervolgens laat ik zien dat deze principes in de praktijk soms tot uitdagingen leiden. Ik sluit af met een visie op een gedemystificeerd pensioenstelsel, interessante onderzoeksvragen en aandachtspunten voor pensioenregulering.

\section{Baron van Münchhausen en het appeltaartprincipe}

Er zijn verschillende thema's bij pensioenfinanciering en pensioenregulering die regelmatig tot discussie leiden. In die discussie verdwijnen algemeen aanvaarde principes soms naar de achtergrond. Vandaag duid ik een dergelijke situatie aan met de term pensioenficties. Ik bespreek er vier. Gegeven de beperkte hoeveelheid tijd vanmiddag lukt het niet om alle mystiek ineens te beschrijven.

Pensioenfictie 1: de juiste rekenrente is het verwachte rendement op de beleggingen

De eerste pensioenfictie gaat over de rekenrente. De fictie is dat de waarde van pensioenaanspraken volgt uit het contant maken van die aanspraken tegen een rekenrente gelijk aan het verwachte rendement op de beleggingen. Het meest gehoorde argument hierbij is dat het pensioenfonds dit rendement op lange termijn verdient. Hier doet zich meteen een belangrijke beperking voor. Het verwachte rendement is niet waarneembaar. Het is slechts mogelijk hier een subjectieve inschatting van te maken. En zoals mijn collega Antoon Pelsser op deze plek heeft laten zien is de modelonzekerheid rondom aandelenrendementen dermate groot we statistisch gezien bar weinig kunnen zeggen over het werkelijke rendement (Pelsser, 2010). Naast het subjectieve karakter leidt disconteren tegen het verwachte rendement tot een verkeerde prikkel. De waarde van pensioenaanspraken is op twee manieren eenvoudig te verlagen. Namelijk door een hoger verwacht rendement te 
veronderstellen. Of door risicovoller te beleggen met een hoger verwacht rendement. Een hoger verwacht rendement verbetert vervolgens per direct de dekkingsgraad. Dit is de verhouding tussen de waarde van de bezittingen en de waarde van de aanspraken in een pensioenfonds.

De consequenties hiervan zijn niet triviaal. Beschouw twee identieke pensioenfondsen, $A$ en $B$, met dezelfde populatie deelnemers, dezelfde pensioenregeling, hetzelfde belegd vermogen en hetzelfde beleggingsbeleid. Het enige verschil is de rekenrente. Stel dat pensioenfonds A disconteert tegen een verwacht rendement van 5 procent en $B$ tegen de risicovrije rente van 3 procent. De dekkingsgraad van pensioenfonds $A$ is dan grofweg 30 procentpunten hoger dan van B. Die hogere dekkingsgraad biedt de deelnemers in fonds $A$ uitzicht op meer indexatie. Dit is echter schijn die bedriegt. Pensioenfonds $A$ is niet rijker of armer dan B. Omdat er niet meer geld in het pensioenfonds zit, zijn het de gepensioneerden in A die de vruchten plukken van de hoge disconteringsvoet. Zij zijn als eerste aan de beurt om hun pensioenuitkering te krijgen. Dit ten koste van de jongeren in A.

Als u nu denkt dat dit in de praktijk niet zo'n vaart loopt dan vergist $u$ zich. De Amerikaanse publieke pensioenfondsen mogen onder de voor hen toepasselijke accountingregels (Government Accounting Standards Board Standards) pensioenaanspraken disconteren tegen het verwachte rendement. Aleksandar Andonov, Rob Bauer en Martijn Cremers laten zien dat de Amerikaanse publieke pensioenfondsen hierdoor een sterke prikkel hebben om risicovol te beleggen en daarmee de dekkingsgraden kunstmatig hoog te houden (Andonov, Bauer en Cremers, 2017). Dit is enerzijds een uitweg om de goed georganiseerde werknemers te vrijwaren van hoge pensioenpremies. En anderzijds een manier voor de Amerikaanse overheden om bezuinigingen en belastingverhogingen af te wentelen. Deze aanpak is helaas economisch gezien een doodlopende weg. Omdat de voorstelling van de financiële situatie rooskleuriger is dan deze economisch gezien is, leven de publieke pensioenfondsen op te grote voet.

Dit is een van de grotere uitdagingen voor de Verenigde Staten en ik ben dan ook benieuwd naar de tweets van President Trump hierover. Aangezien hij omvangrijke belastingverlagingen in zijn presidentiële campagne naar voren bracht, lijkt het onwaarschijnlijk dat er nog geld over is om meer pensioenpremies te betalen. Voor de publieke 
pensioenfondsen rest niets anders forse beleggingsrisico's te blijven nemen in de hoop dat dit een hoog rendement oplevert. Een dergelijke riskante strategie staat in de toezichtwereld bekend als 'gambling for resurrection'. Als u niet bekend bent met deze terminologie, het gaat hier om hetzelfde effect als Baron Karl von Münchhausen die zichzelf aan zijn eigen vlecht uit een moeras trekt.

Pensioenfictie 2: Bij een hoger beleggingsrisico volstaat een lagere pensioenpremie

Dit brengt me bij een tweede pensioenfictie. Het nemen van meer beleggingsrisico leidt in verwachting tot een hoger rendement waardoor een lagere pensioenpremie volstaat om om hetzelfde pensioen te financieren. Om aan te tonen dat dit laatste een fictie is spelen we even een vraag uit de Nationale Wetenschapsquiz. Dit is een leuke economische variant op de jaarlijkse vraag over de wet van Archimedes.

Neem een rationele werknemer die bij een beursgenoteerde onderneming 50.000 euro per jaar verdient. Hiervan bestaat 40.000 euro uit salaris en 10.000 euro uit pensioenpremie. Stel het pensioenfonds besluit meer beleggingsrisico te nemen en legt aan de deelnemer voor dat hij nog maar 8.000 euro pensioenpremie hoeft te betalen. Gaat de werknemer akkoord met dit voorstel? Dit zijn de mogelijke antwoorden:

A. Ja, de werknemer gaat akkoord. Het pensioenfonds gaat immers meer geld verdienen in financiële markten.

B. Ja, de werknemer gaat akkoord mits zijn salaris met 5 procent stijgt.

C.Ja, de werknemer gaat akkoord mits de onderneming een bonusdividend uitkeert.

Terwijl u nadenkt verklap ik alvast dat B het goede antwoord is. Hoewel het verwachte rendement van de pensioenfondsbeleggingen toeneemt, stijgt óók de kans voor de werknemer om met een lager pensioen te eindigen. Hiervoor wil hij een compensatie van 2.000 euro hetgeen overeen komt met een stijging van zijn salaris met 5 procent. Stel dat de werknemer toch akkoord gaat met een lagere pensioenpremie dan spekt hij de aandeelhouders van de onderneming. De 2.000 euro lagere pensioenpremie blijft dan immers in de kas van de onderneming. Het is niet rationeel voor de werknemer om hiermee akkoord te gaan. 
Als $u$ nu denkt dat het hiermee niet zo'n vaart loopt, dan heeft $u$ het mis. De Nederlandse wetgever biedt pensioenfondsen ruimte de zogenaamde kostendekkende premie te berekenen tegen het verwachte rendement. Dit betekent dat pensioenfondsen die meer beleggingsrisico nemen kunnen volstaan met een lagere premie. Omdat dan economisch gezien de premie te laag is heeft dit bijvoorbeeld een negatief effect op het herstel van de dekkingsgraad in geval van een dekkingstekort (DNB, 2016). Het feit dat dit is toegestaan is naar mijn indruk dan ook een politiek compromis bij de totstandkoming van de regelgeving geweest.

\section{Pensioenfictie 3: Aandelen zijn op lange termijn een veilige belegging}

De derde fictie gaat ook over rendement en risico en luidt als volgt: op lange termijn zijn aandelen een veilige belegging. Niet zelden hoor je de redenering dat aandelen weliswaar op korte termijn sterke koersschommelingen laten zien, maar op lange termijn een veilige belegging zijn. Dus voor lange termijn beleggers zoals pensioenfondsen. Dat dit een fictie is wordt duidelijk als we naar de juiste risicomaatstaf kijken. Risico is een lastig te grijpen concept in de economie omdat een unieke definitie ontbreekt.

Nobelprijswinnaar Robert Merton legt intuïtief uit dat risico situatief is bepaald (Merton, 2011): "Risico meet je ten opzichte van wat de risicovrije benchmark is. En het na te streven doel bepaalt wat de risicovrij benchmark is." Als het doel het nakomen van een zekere nominale pensioenuitkering is, dan zijn nominale obligaties de risicovrije benchmark. In een dergelijke context meten we het risico van aandelen dus door het af te zetten tegen een belegging in risicovrije nominale obligaties. Laten we dit inderdaad eens doen en vervolgens de beleggingshorizon in beschouwing nemen. De kans dat het rendement op aandelen lager is dan het risicovrije rendement neemt af met de beleggingshorizon. Dit is eenvoudig te verklaren omdat aandelenkoersen in verwachting harder stijgen dan de koers van de risicovrije belegging. Hierdoor lijkt het alsof het risico van aandelen op lange termijn afneemt.

Niets is minder waar. Deze kansmaat is namelijk een beperkte risicomaatstaf. Economisch gezien is niet alleen de kans op een slechte uitkomst belangrijk. Des te belangrijker is de omvang van een verlies gegeven dat zich een verlies voordoet (Bodie, 1995). Deze risicomaatstaf heet in toezichtjargon 'loss given default'. Als u naar deze risicomaatstaf kijkt dan zijn aandelenbeleggingen risicovol op lange termijn. In Figuur 5 
ziet $u$ het verwachte verlies over alle economische scenario's waarin aandelen minder opleveren dan de risicovrije benchmark. $U$ ziet een toename in de loss given default tot meer dan 40 procent bij een horizon van 20 jaar. Dit laat zien dat aandelen op lange termijn geen veilige beleggingen zijn als de doelstelling risicovrij is.

Figuur 5: Risico van aandelen op lange termijn

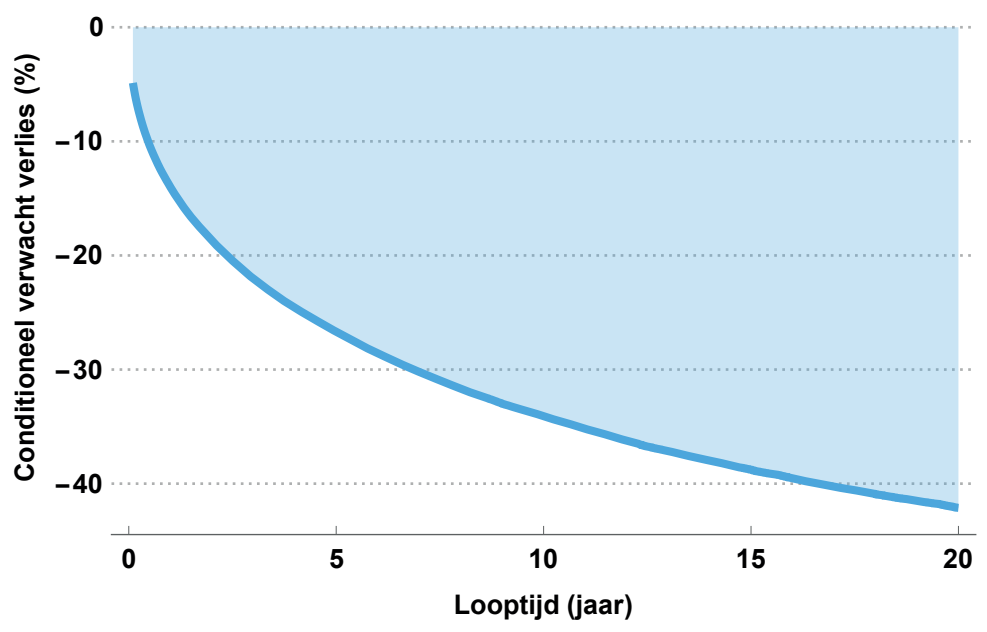

Toelichting: berekening gebaseerd op een verwacht rendement op aandelen van 6 procent en een volatiliteit van aandelenrendementen van 20 procent. De risicovrije rente bedraagt 3 procent.

Hiermee wil ik niet opperen dat pensioenfondsen niet in aandelen moeten beleggen. Integendeel. Er zijn tenminste twee redenen waarom pensioenfondsen aandelen en andere risicodragende beleggingen in de portefeuille opnemen. De eerste heeft te maken met het feit dat ze naast het uitkeren van zekere pensioenaanspraken ook een doelstelling hebben om de koopkracht van die aanspraken op peil te houden (Tamerus, 2011). Toepassing van de definitie van Merton betekent vanuit deze doelstelling dat zogenaamde inflation linked bonds de risicovrije benchmark zijn. Dit zijn obligaties waarvan de aflossing of de couponbetalingen meegroeien met de inflatie. Het Agentschap van de Generale Thesaurie van het Ministerie van Financiën geeft dergelijke obligaties niet uit. De risicovrije reële benchmark is daarmee niet beschikbaar voor Nederlandse pensioenfondsen. Aandelen en andere 
reële beleggingen fungeren dan als een soort 'second best solution' om de inflatie bij te houden. Waarbij overigens flinke discussie in de finance literatuur bestaat over de mate waarin dit het geval is. Een tweede reden, en mijn inziens een beter argument, is dat pensioenfondsen rekening houden met diversificatie tussen het financieel kapitaal en het menselijk kapitaal van de deelnemers. Ik kom hier later uitgebreider over te spreken. Kort gezegd komt het er op neer dat naarmate de contante waarde van het loon van de deelnemers hoger en zekerder is, het financiële kapitaal risicovoller mag worden belegd.

\section{Pensioenfictie 4: Herverdeling creëert waarde}

Een vierde pensioenfictie luidt als volgt: herverdeling creëert waarde. Bij herverdeling in een pensioenfonds stroomt geld van de ene naar de andere groep deelnemers. Op voorhand is bekend om hoeveel geld het gaat. Een voorbeeld is de herverdeling van jong naar oud die verscholen zit in de doorsneesystematiek. Het verschuiven van geld creëert geen economische waarde. De beste manier om dit uit te leggen is het appeltaartprincipe. Mijn kinderen bakken wel eens een taart. Zij weten als geen ander dat als je iemand een groter stuk appeltaart geeft, er voor de anderen minder over blijft. De appeltaart wordt kortom niet groter door deze anders te verdelen. In het pensioendebat bestaat soms verwarring tussen herverdeling en risicodeling. Dat is op zich ook niet gek want beide vallen onder de generieke term solidariteit. Het verschil is dat bij risicodeling niet op voorhand bekend is wie geld ontvangt en wie geld betaalt. Deze vorm van solidariteit verhoogt de welvaart. Waarover straks meer.

\section{Algemeen aanvaarde economische en actuariële principes}

Dit zijn maar een paar ficties die met enige regelmaat opkomen in discussies over pensioenregulering. Dit brengt mij bij de centrale boodschap van deze rede. Pensioenregulering dient gebaseerd te zijn op algemeen aanvaarde economische en actuariële uitgangspunten. Ik beperk me hier tot de bespreking van vijf principes die essentieel zijn voor 'incentive compatible' pensioenregulering. Hiermee doel ik op toezichtregels die pensioenfondsen stimuleren een gedrag te vertonen dat in overeenstemming is met de belangen van zijn deelnemers.

Deze vijf principes zijn bovendien bepalend voor de drie financiële dimensies van pensioen die voor deelnemers belangrijk zijn. Zeg maar 
de financiële hoogte, lengte en breedte van een pensioenkubus. De eerste dimensie is de hoogte van hun pensioenaanspraak. Dit is de verwachte uitkering als ze met pensioen gaan. De tweede dimensie is de onzekerheid rondom de hoogte van hun pensioenaanspraak. Dit is de uitkering die deelnemers krijgen als het economisch mee of tegen zit. Als derde dimensie is voor hen de waarde van de pensioenaanspraken belangrijk. Dit is het bedrag dat ze mee krijgen bij waardeoverdracht tussen twee pensioenfondsen. Het is essentieel al deze dimensies steeds in onderlinge samenhang te zien. Een goede inschatting van je pensioen krijg je alleen door alle zijden van de kubus te zien. Andere financiële aspecten van pensioen zoals maatschappelijk verantwoord beleggen zijn overigens ook essentieel maar vallen voor vandaag buiten het bestek van mijn rede. Niet omdat ze onbelangrijk zouden zijn, maar juist omdat daar een rede op zichzelf voor gerechtvaardigd is. Laten we daarom nu de vijf principes van vandaag langslopen.

\section{Principe 1: Replicatieprincipe}

Het eerste principe is het replicatieprincipe. Dit principe is nodig om de waarde van pensioenaanspraken te bepalen en het luidt als volgt. De marktconsistente waarde van een pensioenaanspraak is gelijk aan de marktwaarde van de beleggingsportefeuille die de aanspraak onder alle eventualiteiten repliceert. Met dit principe zijn pensioenaanspraken eenvoudig te waarderen, ook al worden pensioenaanspraken zelf niet op een markt verhandeld. Het replicatieprincipe houdt in dat identieke kasstromen - qua hoogte, risicoprofiel en looptijd- dezelfde waarde moeten hebben. Als dit niet opgaat ontstaan arbitragemogelijkheden. Arbitrage is een manier om gratis geld te verdienen. En omdat marktpartijen hier gretig op inspringen, blijven dergelijke situaties niet lang bestaan.

Het replicatieprincipe is toepasbaar op alle typen pensioenaanspraken. Ik noem kort hoe het werkt voor de drie soorten pensioenaanspraken die het meest voorkomen. De replicerende beleggingsportefeuille van onvoorwaardelijke pensioenaanspraken in een uitkeringsovereenkomst bestaat uit vastrentende beleggingen die een zeer beperkt kredietrisico kennen. Dus uit overheidsobligaties, obligaties van supranationale instellingen en renteswaps. Bij het opmaken van hun balans hoeven pensioenfondsen de replicerende portefeuille niet zelf te vinden. De Pensioenwet voorziet namelijk in een kortere weg die op exact hetzelfde neerkomt. Namelijk het disconteren van de onvoorwaardelijke aanspraken tegen de voorgeschreven rentetermijnstructuur. 
Voor voorwaardelijke aanspraken bestaat de replicerende beleggingsportefeuille uit optiecontracten die het conditionele karakter nabootsen. Het belangrijkste praktijkvoorbeeld van een dergelijke voorwaardelijke aanspraak is de hoogte van indexatie als functie van de dekkingsgraad. De marktconsistente waarde hiervan is te bepalen met behulp van optiewaarderingsmodellen (Kocken, 2006). Overigens geldt in de huidige pensioenregulering geen verplichting om de marktconsistente waarde van voorwaardelijke indexatie te bepalen. Dit vanwege de discretionaire bevoegdheid van pensioenfondsbestuurders om binnen de wettelijke randvoorwaarden de hoogte van de indexatie te kiezen. Ook dit is naar mijn indruk de resultante van een politiek compromis bij de totstandkoming van de regulering (Broeders, Kellermann en Sleijpen, 2011).

Het laatste voorbeeld is de marktconsistente waarde van aanspraken in een premieovereenkomst. Deze waarde is gelijk aan de marktwaarde van de aanwezige beleggingen. Hier komt geen ingewikkelde Midas formule aan te pas.

\section{Principe 2: Een gratis lunch bestaat niet}

We komen aan bij het tweede algemeen aanvaarde principe: een gratis lunch bestaat niet. Om iets te verkrijgen dat we leuk vinden is het nodig iets anders op te geven. Zo is er geen gratis lunch in de afweging tussen rendement en risico in financiële markten. Een belegger kan een verwachte risicopremie niet verdienen zonder het bijbehorende risico te accepteren. Ook dit principe is waar voor alle soorten pensioenregelingen. Risicovoller beleggen verhoogt niet alleen het verwachte pensioeninkomen. Het verhoogt ook de kans op het niet halen van het geambieerde pensioeninkomen.

Principe 3: Kosten en financiering zijn twee aparte zaken

Het derde principe is dat kosten en financiering een helder onderscheid kennen. Beleggingsrisico's worden vaak genomen vanuit de gedachte dat het hogere verwachte rendement de pensioenkosten verlaagt. Deze redenering gaat mank omdat het de kosten van een pensioenaanspraak en de financiering ervan door elkaar haalt.

Waar het mis gaat is gemakkelijk te zien als we het woord 'pensioenaanspraak' vervangen door het woord 'huis'. Stel een nieuwbouwhuis staat te koop voor een prijs van 250 duizend euro. Of de koper van het huis dit bedrag financiert met eigen middelen of 
met een hypotheek maakt voor de prijs van het huis niet uit. De prijs verandert niet door de financieringswijze. De kosten van het huis gaan alleen omlaag door bijvoorbeeld het woonoppervlak kleiner te maken of door minder luxe materialen te gebruiken. Hetzelfde geldt voor pensioen. Als een pensioenaanspraak 250 duizend euro kost dan heeft de wijze waarop je dit financiert hier geen invloed op. Die kosten gaan alleen omlaag door minder pensioen toe te zeggen. Dus door een lager opbouwpercentage te hanteren of minder indexatie te beloven.

\section{Principe 4: Actief portefeuillebeheer is een zero sum game}

Het vierde principe is dat actief portefeuillebeheer een zero sum game is. Dit behoeft enige toelichting. Het vak dat ik hier aan de universiteit met plezier mag doceren heet 'Institutional Investors'. In dit vak leren studenten dat geavanceerde beleggers via actief portefeuillebeheer een beter beleggingsresultaat nastreven dan het rendement dat ze krijgen door passief in een index te beleggen. Dit extra rendement ('alfa') draagt op zich bij aan de financiering van pensioenaanspraken. Hierbij zijn echter twee opmerkingen op zijn plaats.

De eerste kanttekening is dat actief portefeuillebeheer een 'zero sum game' is. De extra winst voor de ene belegger is een verlies van een andere belegger. En omdat beleggers extra kosten maken voor actief portefeuillebeheer is dit op geaggregeerd niveau zelfs een 'negative sum game'. Per saldo kost het de maatschappij geld (French, 2008). Dit is overigens deels te rechtvaardigen omdat actief portefeuillebeheer nodig is om te zorgen dat de prijzen van aandelen en andere beleggingen de onderliggende waarde representeren. Een fenomeen dat bekend staat als 'price discovery'. Onderzoek naar de beleggingskosten van pensioenfondsen en andere institutionele beleggers is wat dat betreft een belangrijk thema dat terecht steeds meer aandacht krijgt (Broeders, van Oord en Rijsbergen, 2016).

Een tweede kanttekening is dat het heel moeilijk blijkt om jaar-op-jaar alfa te generen. Dit volgt uit het bestuderen van 'de fundamentele wet van actief portefeuillebeheer' (Grinold en Kahn, 2000). Deze wet laat zien dat alfa het product is van drie factoren: hoe goed de belegger is in voorspellen, hoe vaak kan hij handelen en hoeveel risico hij neemt. Voorspellen van financiële markten is koffiedik kijken. Een belegger die een beetje goed voorspelt kan niettemin door veel te handelen extra rendement genereren. Dit gaat dan echter weer gepaard met extra kosten die alfa drukken. 
Principe 5: Diversificatieprincipe

Het vijfde en laatste principe is dat het poolen van het individuele langlevenrisico de welvaart verhoogt. Dit principe gaat over risicodeling. leder individu is onzeker over zijn resterende levensverwachting. Dit risico is diversifieerbaar: door het risico te spreiden over een grote groep deelnemers middelt het risico uit. Op het niveau van een groot collectief aan deelnemers is dit risico daardoor verwaarloosbaar klein. In plaats van individueel te sparen voor de situatie dat je heel oud wordt, hoeft het collectief nog maar te sparen voor de gemiddelde levensduur.

Dit is te vergelijken met het werpen van een dobbelsteen. Bij slechts een worp is de kans op een, twee, drie, vier, vijf of zes ogen precies een zesde. Als je de dobbelsteen echter heel vaak werpt gaat het gemiddelde aantal ogen over alle worpen naar 3,5. Figuur 6 toont dit effect aan. Bij meer en meer worpen met de dobbelsteen tendeert het gemiddelde steeds meer naar het gemiddelde van de echte kansverdeling. Dit is echter nooit perfect. Puur door toeval overleven altijd iets meer of iets minder deelnemers dan de kansverdeling voorspelt.

Figuur 6: Diversificatie-effect bij gooien dobbelsteen

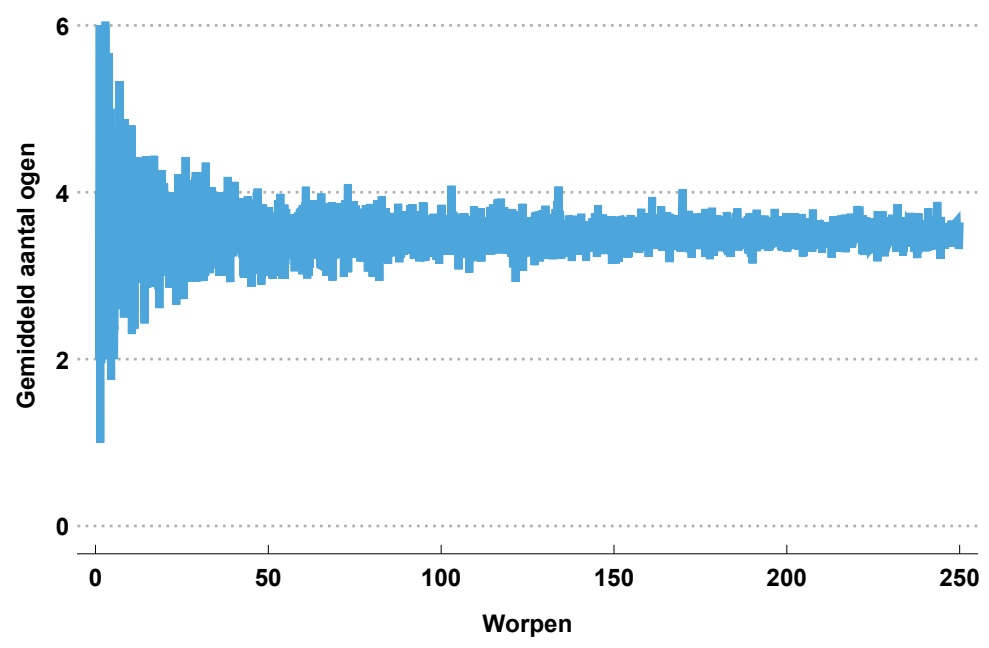

Naast het individuele langlevenrisico hebben pensioenfondsen ook te maken met systematisch langlevenrisico. Dit is het risico dat de levensverwachting van alle deelnemers stijgt (of daalt). Dit is een 
niet-diversifieerbaar risico. Meer deelnemers aan het pensioenfonds toevoegen verkleint het risico niet. We nemen de dobbelsteen weer in de hand. We pakken een stift en beelden de stijging van de levensverwachting uit door op elke zijde van de dobbelsteen een extra oog te tekenen. Het gemiddelde van de kansverdeling stijgt hierdoor. Bij heel veel worpen gaat het gemiddelde nu naar 4,5 zoals $u$ kunt zien in Figuur 7 . Een manier om een dergelijke schok op te vangen is het verhogen van de pensioengerechtigde leeftijd.

Figuur 7: Diversificatie-effect bij dobbelsteen (elke zijde een oog extra)

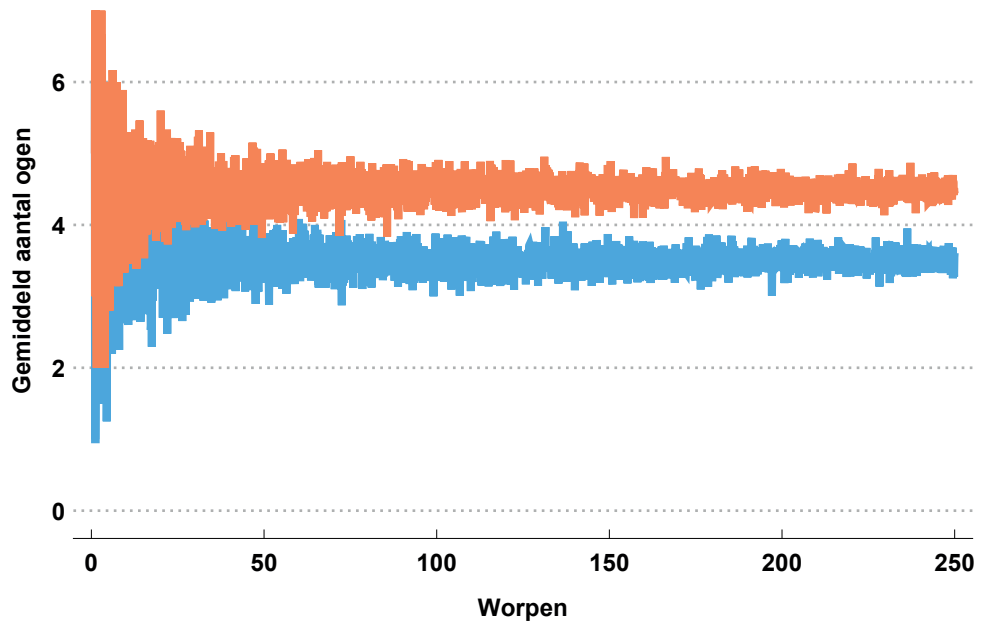

\section{Enkele uitdagingen bij de toepassing van de algemeen aanvaarde principes in de praktijk}

Al deze algemeen aanvaarde economische en actuariële principes hebben een stevige wetenschappelijke basis en maken het leven voor regelgevers makkelijker. Dat zou je althans denken. Toch is dit niet altijd zo. Ik wil graag twee punten toelichten waar uitdagingen ontstaan. Het eerste punt betreft een verschil tussen de juridische en economische benadering van pensioenaanspraken. Het tweede punt is de waardering van pensioenaanspraken met een zeer lange looptijd. 
Uitdaging 1: juridische versus economische benadering van pensioenaanspraken

De meeste Nederlandse werknemers bouwen pensioenaanspraken op in een uitkeringsovereenkomst. Het blijkt dat in die pensioenregeling een onderscheid is tussen wat de deelnemer krijgt als hij het pensioenfonds verlaat en wat hij krijgt als hij in het pensioenfonds blijft. Het eerste duid ik aan met de juridische visie en het tweede met de economische visie (Boelaars et al., 2015). Een alternatieve benaming voor dit onderscheid is aanspraken bij discontinuïteit respectievelijk aanspraken bij continuïteit. Dezelfde kubus heeft verschillende financiële dimensies. Het een is niet beter dan het ander. Het gaat er om dat er een verschil is. Dit verschil creëert complexiteit.

In de huidige pensioenregulering staat de juridische visie op aanspraken centraal. De aanspraken zijn de over het arbeidsverleden opgebouwde pensioenaanspraken verhoogd of verlaagd met toeslagen en kortingen die reeds zijn toegekend. Omdat deze pensioenaanspraken betrekking hebben op het verleden is er geen onzekerheid. De waarde ervan volgt dan ook uit het disconteren met de risicovrije marktrente. Deze waarde krijgt de deelnemer mee als hij van werkgever of van bedrijfstak verandert en zijn pensioen overdraagt. Als de deelnemer in het fonds blijft dan weet hij echter met zekerheid dat hij de zekere juridische aanspraken niet krijgt. Deze juridische waardering laat namelijk de waarde van indexaties of kortingen die nog gaan optreden buiten beschouwing.

Als de deelnemer in het pensioenfonds blijft zijn die toekomstige indexaties en kortingen voor hem relevant. In het fonds geniet hij de economische aanspraken. De kans op en de hoogte van de nog te ontvangen toeslagen en kortingen zijn dan medebepalend voor de economische onzekerheid en waarde van de pensioenaanspraken.

De juridische en economische waarde komen bij een uitkeringsovereenkomst veelal niet overeen. Zo is bijvoorbeeld het indexatiepotentieel in een pensioenfonds met een flinke buffer hoog. De economische waarde van de aanspraken is in zo'n geval hoger dan de juridische waarde. Bij lage dekkingsgraden, dus in het geval van dekkingstekorten, overschat de juridische waarde juist dus de economische waarde van de pensioenaanspraken. 
Hoewel de wetgever een dergelijk verschil waarschijnlijk niet bewust heeft gecreëerd, leidt het in de praktijk tot belangrijke complicaties. Het zadelt deelnemers op met een ingewikkeld financieel vraagstuk als ze van baan wisselen. De vraag of het verstandig is om gebruik te maken van het recht op individuele waardeoverdracht vergt namelijk kennis van zowel de juridische waarde die de deelnemer krijgt bij vertrek als de economische waarde die de deelnemer als slaper geniet indien hij zijn aanspraken in het pensioenfonds achterlaat. En kennis van wat hij er voor terug krijgt in het nieuwe pensioenfonds. Verder is het voor een deelnemer een hele toer om een optimale financiële planning te maken daar hij slechts kan varen op informatie over de juridische aanspraken die hij heeft opgebouwd. Naast informatie over de onzekerheid van de economische aanspraken pleit ik er voor dat de deelnemer ook inzicht krijgt in de waarde van zijn aanspraken. Op het ideale UPO staan dus alle zijden van de pensioenkubus. Een van de kansen voor een nieuw pensioenstelsel is bovendien om het verschil tussen juridisch en economisch te overbruggen. Dit is mijn inziens ook goed mogelijk en maakt het pensioenstelsel aanzienlijk eenvoudiger.

\section{Uitdaging 2: Waardering van langlopende pensioenaanspraken}

Een tweede uitdaging betreft de waardering van zeer langlopende pensioenaanspraken en de toepassing van het replicatieprincipe. Pensioenfondsen hebben te maken met pensioenaanspraken die pas over vele tientallen jaren tot uitkering komen. De jongste deelnemer in een uitkeringsovereenkomst bouwt bijvoorbeeld een aanspraak op die pas over, zeg, 45 jaar voor het eerst tot uitkering komt. Toezeggingen die een dergelijke lange tijdspanne overbruggen zien we eigenlijk nergens in de economie. Overheden, die per definitie een zeer lange horizon hebben, geven bijvoorbeeld geen obligaties uit met deze lange looptijd. Er is wel een markt voor renteswaps met een zeer lange looptijd. De vraag is echter of de liquiditeit in die renteswaps voldoende is om tot een faire waardering te komen.

Hier komt de Ultimate Forward Rate (UFR) in beeld. U weet nog wel, de aanleiding voor de explosies in rekenrentetweets. De UFR betreft de prijs waartegen de eenjaars rente op hele lange termijn kan worden vastgezet (Commissie UFR, 2013). Kort gezegd, het is een aanname over de hele korte rente maar dan op hele lange termijn. Deze UFR komt vervolgens via een ingewikkelde rekenmethode in de rekenrentes voor lange looptijden terecht. Die methode zal ik u vandaag besparen. 
Daarentegen wil ik wel stil staan bij het belang van een realistische waardering van verplichtingen (Broeders, de Jong en Schotman, 2016). Voorstanders geven aan dat de UFR de dekkingsgraad van pensioenfonds minder gevoelig maakt voor eventuele verstoringen in de minder liquide segmenten van de financiële markten. Daar staat tegenover dat als de UFR niet realistisch is, een pensioenfonds zijn financiële positie beter of slechter voor stelt dan deze werkelijk is. Dit leidt tot twee ongewenste effecten.

Het eerste ongewenste effect is dat een te hoge UFR via een lagere waarde van de pensioenaanspraken optisch leidt tot een betere dekkingsgraad. En omdat door gebruik van een onrealistische UFR niet meer geld in het fonds komt ontstaat herverdeling. Het appeltaartprincipe laat zien dat deze loopt van jong naar oud. Ouderen krijgen immers als eerste hun stuk appeltaart. Omgekeerd betekent een te lage UFR herverdeling van oud naar jong. Het doel van een UFR is mijn inziens niet om her te verdelen. Wat dat betreft is het vanuit governance optiek goed dat de bepaling van de UFR is belegd bij een onafhankelijke commissie van finance hoogleraren.

Het tweede ongewenste effect is dat de UFR leidt tot een prikkel om risicovoller te beleggen. Met name als de UFR hoger ligt dan de marktrente. Of preciezer gezegd, als de rekenrente afgeleid van de UFR hoger ligt dan de marktrente. Dit omdat het pensioenfonds dan weet dat het met obligatiebeleggingen niet in staat is het hogere rendement te halen. De enige mogelijkheid om meer rendement te maken is om risicovoller te beleggen. Dit maakt pensioenaanspraken echter meer onzeker. Het doel van een UFR is mijn inziens niet om pensioenaanspraken risicovoller te maken.

Ik pleit daarom voor een 'UFR-vrij' pensioensysteem. De UFR is niet het probleem. Maar het feit dat we jonge deelnemers zekere pensioenaanspraken beloven met een looptijd van vele tientallen jaren. Dit is eigenlijk onlogisch. Een jonge deelnemer heeft veelal nog geen behoefte aan een zekere pensioenaanspraak. Hij heeft voldoende menselijk kapitaal om beleggingsrisico's te nemen met zijn pensioenkapitaal. Dit brengt mij bij het laatste deel van deze rede. 


\section{Het pensioenfonds als functioneel platform}

Hoewel het Nederlandse pensioenstelsel bijzonder goed scoort ten opzichte van de meeste andere landen zijn er ook redenen om de toekomstbestendigheid te vergroten. Zo is het belangrijk het stelsel eenvoudiger te maken en meer rekening houden met de kenmerken van deelnemers. Verder is het wenselijk herverdelingen tussen deelnemers te verminderen. In een vergrijzende samenleving en een dynamische arbeidsmarkt leggen herverdelingen druk op de houdbaarheid van het stelsel. Met een eenvoudiger, meer flexibel pensioenstelsel zonder onnodige herverdelingen wordt Nederland weer wereldkampioen pensioenen.

In dit laatste deel van mijn rede wil ik daarom stilstaan bij de toekomst van ons pensioenstelsel. En wel aan de hand van vier thema's. Het pensioenfonds als functioneel platform, het belang van heldere eigendomsrechten, de transitie naar een nieuw stelsel en ik sluit af met een belangrijke observatie over pensioenregulering. In al deze thema's zitten vragen besloten die zich uitstekend lenen voor wetenschappelijk onderzoek.

Thema 1: Het pensioenfonds als functioneel platform

Het eerste thema gaat over het pensioenfonds als functioneel platform. In Nederland loopt sinds het verschijnen van de rapporten van de Commissie Goudswaard en de Commissie Frijns in 2010 een beleidstraject over het toekomstbestendig maken van het pensioenstelsel. Dit traject loopt langs de contouren van mogelijke contractvormen. Verschillende innovatieve contractenvormen liggen op de tekentafel. De contractdiscussie is een uitdaging omdat het vrij lastig is een contract te verzinnen dat optimaal is voor alle deelnemers waar het voor is bedoeld.

Dat die optimalisatie een uitdaging is zien we bij het ontleden van een pensioenfonds naar de verschillende functies die het verricht voor zijn deelnemers. De belangrijkste functies zijn sparen, beleggen, ontsparen en het delen van risico's (Bovenberg en Nijman, 2014 en Broeders en Minderhoud, 2015). Al deze functies samen richten zich op een optimale spreiding van consumptie over de levenscyclus van deelnemers. En omdat deelnemers op veel punten een heterogene groep vormen is dat optimum verschillend. Denk aan verschillen in leeftijd, inkomen, vermogen, levensverwachting, arbeidsmobiliteit, risicodraagvlak en risicobereidheid. 
Laten we de vier functies in meer detail bekijken. De eerste functie is die van sparen. Het doel van sparen is vermogensopbouw. De centrale vraag bij de spaarbeslissing is welk deel van het inkomen opzij wordt gezet voor pensioen. Dit wordt afgestemd op de pensioenambitie van deelnemers. In Nederland spaart momenteel ruim 90 procent van de werknemers voor hun pensioen. Dit is het gevolg van de (grote) verplichtstelling die ondernemingen in bepaalde bedrijfstakken verplicht tot deelname aan een bedrijfstakpensioenfonds. Een pensioenspaarplicht is mijn inziens een 'no brainer' in een nieuw pensioenstelsel. Zonder een dergelijke plicht sparen deelnemers te laat en te weinig (Bodie en Prast, 2012).

De tweede functie is beleggen. Het doel van beleggen is vermogensgroei. Het ingelegde spaargeld vindt zijn weg naar de financiële markten om rendement te maken. De pensioendoelstelling, de beleggingsovertuigingen, het risicodraagvlak en de risicobereidheid van de deelnemers bepalen de optimale afweging tussen rendement en risico in financiële markten. Een belangrijke bepalende factor hierbij is het menselijk kapitaal. Dit is de contante waarde van het loon dat de deelnemer in de toekomst verdient. De omvang en het risicoprofiel van het menselijke kapitaal bepalen in belangrijke mate het risicodraagvlak van een deelnemer. Indien het menselijk kapitaal hoog is en weinig risico kent, dan is diversificatie van het rendement op financieel kapitaal en op menselijk kapitaal aantrekkelijk (Bodie, Merton en Samuelson, 1992). Dit betekent dat het optimaal is om met het financiële kapitaal risico's te nemen. Ouderen hebben deze mogelijkheid minder omdat hun menselijk kapitaal lager is. In de praktijk geldt leeftijd vaak als benadering voor menselijk kapitaal. Onderzoek naar de optimale beleggingsstrategie over de levenscyclus en de rol van beleggingsovertuigingen en van menselijk kapitaal daarin zijn uitgelezen onderzoeksthema's binnen mijn vakgebied.

De derde functie betreft ontsparen. Het doel van ontsparen is gericht op het realiseren van een levenslange uitkering. Om het pensioenvermogen optimaal over de resterende levensverwachting uit te keren moet rekening worden gehouden met het verwachte actuariële resultaat en de zogenaamde projectierente. Dit laatste is een aanname over het beleggingsrendement na pensionering. Bij het bepalen van de hoogte van de projectierente komen de eerder genoemde algemeen aanvaarde economische principes heel goed van pas (Bovenberg, Nijman en Werker, 2016). Zo is het mijn inziens niet verstandig om in die projectierente 
reeds vooruit te lopen op nog te behalen rendementen. Dit vergroot het risico op tegenvallers als de verwachte rendementen zich niet realiseren. Ontsparen is een uitgelezen onderwerp voor wetenschappelijk onderzoek.

De vierde functie is risicodeling. Het doel van deze laatste functie is het minimaliseren van de impact van biometrische risico's op pensioenuitkeringen. Delen van het individuele langlevenrisico is een efficiënte manier om deelnemers te verzekeren van een inkomen ook in het geval zij een zeer hoge leeftijd bereiken. $U$ herinnert zich de dobbelsteen. Ook gaat het hier om het verzekeren van arbeidsongeschiktheid en nabestaandenpensioen.

Het pensioenfonds zie ik als een platform dat deze vier functies bijeenbrengt en optimaal inzet voor de deelnemers. Een belangrijke toegevoegde waarde van het onderscheiden van de functies op een platform is dat zichtbaar wordt dat de output van de ene functie fungeert als input van de volgende functie. Zo is bijvoorbeeld de output van sparen beschikbaar als input voor beleggen. Vervolgens is de output van beleggen de input voor ontsparen. De prestatie van iedere functie kan op deze wijze afzonderlijk worden gemeten (Broeders en Minderhoud, 2015). Ook is het platform in staat om garanties aan te bieden. Deze maken het pensioen - met name voor oudere deelnemers - voorspelbaarder, transparanter en begrijpelijker. Het platform kan de garantie managen zonder het te vermengen met de beleggingsfunctie.

\section{Thema 2: Heldere economische eigendomsrechten}

Een belangrijke voorwaarde om de vier functies optimaal voor de deelnemer in te zetten is door heldere economische eigendomsrechten te definiëren. Eigendomsrechten zijn nu eenmaal essentieel voor een goed functionerende economie. Douglass North ontving in 1993 de Nobelprijs voor de economie nadat hij had laten zien hoe belangrijk eigendomsrechten zijn geweest voor de sterke groei van de Westerse economie. Eigendomsrechten geven individuen en bedrijven prikkels om te innoveren en te produceren en beschermen hen tegen 'rentseeking'. Rent-seeking - ook wel politieke rente genoemd - is de poging van individuen of instituties om financieel voordeel te behalen via de politiek in plaats van via productie. Rent-seeking verlaagt de welvaart, bijvoorbeeld omdat het leidt tot sociale spanningen. Veel regels en instituties in de maatschappij hebben dan ook als doel 
om eigendomsrechten te beschermen: notariële aktes, auteursrecht, aandeelhoudersbewijzen, het kadaster en de rechtspraak om maar enkele voorbeelden te noemen. Hoe beter eigendom vastligt, des te kleiner is de kans op rent-seeking gedrag.

Pensioen is voor veel Nederlanders een van de grootste vermogensbestanddelen. Daarom is het wenselijk de eigendomsverhoudingen van de enorme Nederlandse pensioenspaarpot zo helder mogelijk vast te leggen met als numéraire het persoonlijke pensioenvermogen. Voor iedere deelnemer is dan duidelijk welk stuk appeltaart van hem is. Dit heeft belangrijke voordelen waarvan ik er vijf graag kort bespreek.

Een, de juridische en economische waarde vallen voortaan samen. Dit vermindert de complexiteit van het pensioenstelsel. De beslissing tot overdracht van pensioen is eenvoudiger en het creëert de basis voor deelnemers om een optimale financiële planning te maken.

Twee, het creëert ruimte voor flexibiliteit en maatwerk. Het pensioenplatform is in staat de vier functies te optimaliseren voor deelnemers met verschillende kenmerken. Eventuele nieuwe stelselwijzigingen zijn makkelijker door te voeren met respectering van bestaande eigendomsrechten.

Drie, het biedt bescherming tegen rent-seeking. Herverdeling wordt ingeperkt of in maatschappelijk geaccepteerde situaties expliciet gemaakt. Veranderingen in de pensioenregeling of in pensioenregulering hebben geen invloed op het eigendom van de deelnemers. Zo leiden bijvoorbeeld veranderingen in het beleggingsbeleid niet tot herverdelingen tussen groepen deelnemers. In een systeem met persoonlijke pensioenvermogens speelt de UFR niet langer een cruciale rol bij het waarderen van pensioenaanspraken. Die waarde volgt namelijk uit de waarde van de beleggingen.

Vier, er bestaat geen 'governance gap'. Het pensioenfondsbestuur vertegenwoordigt alleen de deelnemers in het pensioenfonds (Ambachtsheer, 2015). Het bestuur van het fonds hoeft geen rekening te houden met de belangen van de werkgever of met die van generaties die nog toe gaan treden tot het pensioenfonds. Dit reduceert (de kosten van) agency problemen. 
Vijf, er is geen discontinuïteitsrisico. Als een onderneming of een bedrijfstak kleiner wordt of verdwijnt, heeft dat geen gevolgen voor het risicodraagvlak. Omdat tekorten per definitie zijn uitgesloten, is het altijd aantrekkelijk voor nieuwe deelnemers om toe te treden tot het pensioenplatform.

\section{Thema 3: De transitie naar een nieuw stelsel}

De combinatie van een persoonlijk pensioenvermogen en het pensioenfonds als functioneel platform is in mijn ogen de basis voor een nieuw pensioenstelsel. Een belangrijke horde naar een nieuw pensioenstelsel is de transitie. Een van de onderdelen van de transitie is het afschaffen van de doorsneesystematiek die het huidig stelsel kenmerkt. De doorsneesystematiek betekent dat elke deelnemer dezelfde pensioenaanspraken opbouwt (als percentage van het pensioengevend salaris) en daarvoor dezelfde premie inlegt (als percentage van het pensioengevend salaris). Dit lijkt fair, maar economisch gezien leidt het tot herverdeling. Dit vergt enige uitleg. De doorsneesystematiek gaat uit van de gemiddelde beleggingshorizon van alle deelnemers. Deze aanpak onderschat de lange beleggingshorizon van jongeren en daardoor betalen zij te veel voor de opbouw van hun pensioenaanspraken. Dit meerdere is voor het financieren van de opbouw van pensioenaanspraken van oudere werknemers. De doorsneesystematiek leidt dus tot herverdeling van jong naar oud. Het lijkt breed gedragen dat aan deze vorm van herverdeling een einde dient te komen. Dit kan door een overstap te maken naar een systeem met actuarieel faire premies.

Het afschaffen van de doorsneesystematiek dient echter zorgvuldig te gebeuren. Door het afschaffen gaan deelnemers die al in het stelsel zitten de subsidie mislopen die ze anders over het tweede deel van de opbouwfase zouden hebben ontvangen. De twee kernvariabelen die deze herverdeling drijven zijn verschillen in beleggingshorizon en het niveau van de rente. De hoogte van de herverdeling volgt vervolgens uit een vergelijking van de actuarieel faire premie met de doorsneepremie.

Laten we eens een eenvoudig voorbeeld bij de horens pakken. Stel we hebben een pensioenfonds met een jonge en een middelbare deelnemer. De jonge deelnemer heeft nog 40 jaar te gaan tot aan pensioen en de middelbare deelnemer nog 20 jaar. Door de actuarieel faire premie voor beide deelnemers op te tellen en bij helfte te verdelen ontstaat de doorsneepremie. Voor het gemak zie ik af van (verschillen in) 
overlevingskansen. Tabel 4 laat zien hoe de actuarieel faire premie en de doorsneepremie verschillen.

Tabel 4: Actuarieel faire premie en doorsneepremie

\begin{tabular}{|c|c|c|c|}
\hline $\begin{array}{l}\text { Leeftijd } \\
\text { deelnemer }\end{array}$ & $\begin{array}{l}\text { Actuarieel faire } \\
\text { premie }\end{array}$ & Doorsneepremie & Herverdeling \\
\hline $\begin{array}{l}\text { Middelbaar } \\
\text { (20 jaar tot } \\
\text { pensioen) }\end{array}$ & $P[20]$ & $\begin{array}{l}\frac{1}{2}(P[20] \\
+P[40])\end{array}$ & $\begin{array}{l}\frac{1}{2}(P[20] \\
-P[40])\end{array}$ \\
\hline $\begin{array}{l}\text { Jong } \\
\text { (40 jaar tot } \\
\text { pensioen) }\end{array}$ & $P[40]$ & $\begin{array}{l}\frac{1}{2}(P[20] \\
+P[40])\end{array}$ & $\begin{array}{l}-\frac{1}{2}(P[20] \\
-P[40])\end{array}$ \\
\hline
\end{tabular}

Neem vervolgens aan dat de rente gelijk is aan o procent. De actuarieel faire premie voor iedere euro pensioenopbouw voor beide deelnemers is 1 euro. De totale premie is 2 en de doorsneepremie is 1 euro. Oftewel bij een rente van o is de actuarieel faire premie gelijk aan de doorsneepremie. Het verschil in beleggingshorizon doet er nu niet toe. Met het afschaffen van de doorsneesystematiek is bij een rente van o geen geld gemoeid. Met iets meer wiskunde rekenen we uit bij welk renteniveau de herverdeling maximaal is. Dit is bij een rente van 3,5 procent. Van elke ingelegde euro gaat dan 12,5 cent van de jonge naar de middelbare deelnemer zoals $\mathrm{u}$ ziet in Tabel 5 . Bij hogere rentes is de herverdeling weer lager. Bij een rente van 5 procent is de herverdeling bijvoorbeeld lager dan de maximale herverdeling.

Tabel 5: Herverdeling doorsneesystematiek bij verschillende rentes

\begin{tabular}{|c|c|c|c|}
\hline $\begin{array}{l}\text { Leeftijd } \\
\text { deelnemer }\end{array}$ & $\begin{array}{l}\text { Actuarieel faire } \\
\text { premie }\end{array}$ & Doorsneepremie & Herverdeling \\
\hline & Rente $=0 \%$ & & \\
\hline Middelbaar & 1 & 1 & 0 \\
\hline \multirow[t]{2}{*}{ Jong } & 1 & 1 & 0 \\
\hline & Rente $=3,5 \%$ & & \\
\hline Middelbaar & 0,500 & 0,375 & 0,125 \\
\hline \multirow[t]{2}{*}{ Jong } & 0,250 & 0,375 & $-0,125$ \\
\hline & Rente $=5 \%$ & & \\
\hline Middelbaar & 0,377 & 0,259 & 0,117 \\
\hline Jong & 0,142 & 0,259 & $-0,117$ \\
\hline
\end{tabular}


Bij het afschaffen van de doorsneesystematiek bieden de algemeen aanvaarde economische en actuariële principes een belangrijke helpende hand. Zo is het onderscheid tussen kosten en financiering hier cruciaal. Bij de doorsneesystematiek wordt de premie-inleg van jongeren deels gebruikt om de opbouw van pensioenaanspraken van oudere medewerkers te financieren. Dit brengt een omslagelement in ons verder kapitaalgedekte pensioenstelsel. Financiering op basis van kapitaaldekking of op basis van omslagfinanciering maakt de kosten van eenzelfde pensioenaanspraak niet hoger of lager. Het kost wat het kost. Dit geldt dus ook voor de transitielast. Verder leert het geen-gratislunch principe ons dat de kosten van de transitie niet afhangen van het risicoprofiel van de beleggingen. De kosten veranderen niet door meer of minder beleggingsrisico te nemen. Anders betekent dit dat twee verder identieke fondsen een verschillende transitielast hebben als een fonds besluit om in de toekomst meer of minder risicovol te beleggen. Berekeningen die wel laten zien dat het beleggingsbeleid van invloed is op de transitielast zijn strijdig met de algemeen aanvaarde economische principes.

\section{Thema 4: Pensioenfondsen en systeemrisico's}

Het kan natuurlijk niet anders dan dat ik vanuit mijn leerstoel afsluit met een boodschap over pensioenregulering. Sinds de crisis die in 2008 werd gemarkeerd met de val van Lehman Brothers, is veel veranderd op het gebied van regelgeving en toezicht. De eisen, reikwijdte en intensiteit van financiële regulering zijn de afgelopen jaren flink toegenomen. Zo zijn de eisen voor omvang en kwaliteit van het buffervermogen toegenomen. De reikwijdte van regulering is uitgebreid naar instellingen en onderdelen van het financiële systeem die eerst niet werden gereguleerd. Bovendien is de intensiteit van toezicht toegenomen. Bijvoorbeeld doordat banken voortaan te maken hebben met een supranationale toezichthouder. Dit alles draagt bij aan een financieel systeem dat weerbaarder is.

Ook pensioenregulering heeft belangrijke veranderingen doorgemaakt. De buffereisen zijn toegenomen en de regels voor indexatie zijn aangescherpt. Daarnaast zien we dat pensioenfondsen rente- en valutarisico's afdekken met behulp van derivaten. De regels rondom derivaten worden strenger. Dit laatste heeft belangrijke gevolgen voor het liquiditeitsbeheer van pensioenfondsen om aan onderpandeisen te voldoen. De implicaties hiervan zijn een interessant en nog grotendeels braakliggend onderzoeksterrein. Hoewel je kunt beargumenteren dat 
de nieuwe regelgeving en risicobeheersing de pensioensector robuuster hebben gemaakt is het oppassen dat die conclusie niet voorbarig is.

Een mogelijk onbedoeld effect is dat pensioenfondsen door regulering meer op elkaar gaan lijken (Broeders et al., 2016). Ze vormen een meer homogene groep in het geval ze hetzelfde gedrag vertonen. Een situatie die in de limiet vergelijkbaar is met een nationaal pensioenfonds. Dit betekent dat het systeemrisico van de pensioensector mogelijk toeneemt. De eerste onderzoekingen die ik hier naar heb gedaan laten hier inderdaad indicaties voor zien. De veranderingen in dekkingsgraden lijken over de tijd steeds meer op elkaar. Dit volgt uit Figuur 8. $U$ ziet hier de kansverdeling van de correlatie tussen de relatieve dekkingsgraadveranderingen van elke combinatie van twee pensioenfondsen (Mantegna en Stanley, 2000). De kansverdeling is gebaseerd op een 'balanced panel' van 171 pensioenfondsen over de periode eind 2008 tot en met eind 2016. Die periode heb ik opgedeeld in 4 blokken van elk 24 maanden. Bij 171 pensioenfondsen is het aantal unieke combinaties van 2 gelijk aan 14.535 (=171!/(2! (171-2)!). Dat lijkt erg veel, maar het is bij lange na niet zo veel als het aantal mogelijkheden van een Rubik kubus. De bovenste grafiek betreft de kansverdeling gebaseerd op de jaren 2009 en 2010. De onderste grafiek op 2015 en 2016. Twee zaken vallen op in de figuur. Ten eerste is de onderlinge correlatie in alle periodes hoog. Dekkingsgraadveranderingen van pensioenfondsen zijn dus sterk gecorreleerd. Eenvoudig gezegd, het gaat met pensioenfondsen allemaal tegelijk de goede of de minder goede kant op. Ten tweede loopt die onderlinge correlatie steeds verder op in de tijd. $U$ ziet van boven naar beneden de kansverdeling steeds verder opschuiven naar rechts. Dit is een indicatie dat het systeemrisico van de pensioensector toeneemt. Voor de impact van systeemrisico's verwijs ik graag naar de documentaire 'Boom Bust Boom' (Kocken en Jones, 2014). Academisch onderzoek naar systeemrisico's en de mitigatie ervan lijkt me essentieel voor pensioenregulering gebaseerd op algemeen aanvaarde economische en actuariële principes. 
Figuur 8: Kansverdeling correlatiecoëfficiënten pensioenfondsen (2009-2016)

0.20

0.15

0.10

0.05

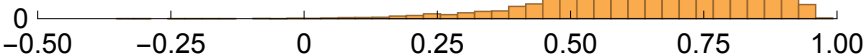

0.20

0.15

0.10

0.05

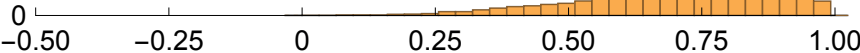

0.20

0.15

0.10

0.05

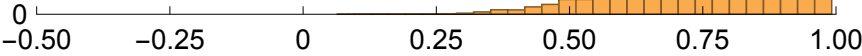

0.20

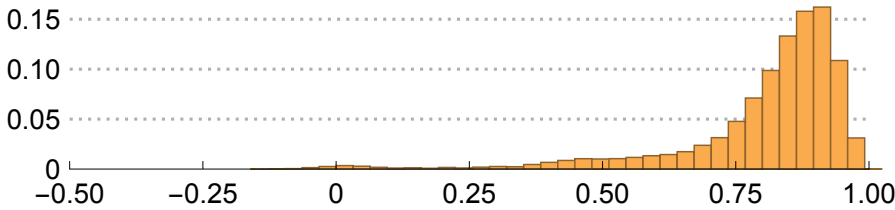

Bron: De Nederlandsche Bank, van boven naar beneden is de kansverdeling van correlatiecoëfficiënten berekend over de maandelijkse relatieve dekkingsgraadmutaties voor 2009/10, 2011/12, 2013/14 en 2015/16. Hier is uitgegaan van de actuele dekkingsgraad van een 'balanced panel' van 171 pensioenfondsen. 


\section{Woord van dank}

Dames en heren, het is de hoogste tijd voor woorden van dank. Om te voorkomen dat de duur van dit dankwoord die van de oratie overstijgt ben ik genoodzaakt het beperkt maar vooral ook gemeend te houden. Ik wil het College van Bestuur van de Universiteit Maastricht en de Directie van De Nederlandsche Bank hartelijk danken voor het voorrecht om de leerstoel pension finance and regulation te mogen bekleden. In het bijzonder ben ik Olaf Sleijpen, Jaap Bos, Piet Eichholtz en Paul Hilbers zeer erkentelijk voor hun inzet en stimulans om dit ideaal te verwezenlijken. Dat geldt evenzeer voor mijn promotores Theo Nijman, Klaas Knot en Frans de Roon. Het is bijzonder inspirerend om academisch onderzoek en onderwijs aan deze prachtige universiteit in een stad met grote economisch-historische betekenis te mogen combineren met strategisch beleidswerk bij een bank die in het hart van de financiële wereld klopt. De collega's van de Finance Department hier in Maastricht en van de afdeling Strategie in Amsterdam hebben een geweldige eigenschap gemeen en dat is een niet aflatend enthousiasme om nieuwe economische inzichten te creëren. Ik zie er naar uit om dit enthousiasme de komende jaren samen met Rob Bauer over te brengen naar Annick en Matteo, onze PhD studenten. Vooruitgang in academisch onderzoek komt tot stand door samenwerken. Grote erkentelijkheid dan ook voor de coauteurs die me altijd van energie voorzien om nog een stapje extra te maken.

On a journey through the mystical world of pensions one has the privilege to meet exceptional people. The man who made a big impression on me deserves special attention today. Not only is he an outstanding and dedicated academic, he is also one of the most impressive and enthusiastic narrators you can ever meet. But above all Zvi Bodie is the all-around good guy. Without his inspiration to discover economic fallacies this inaugural lecture would not have been the same.

Lieve vriendin en kinderen het is een vrolijk en kleurrijk feest met jullie!

Geachte aanwezigen, $u$ allen dank ik voor uw aandacht en komst naar Maastricht vandaag.

Ik heb gezegd. 


\section{Literatuur}

- Ambachtsheer, Keith (2015), Improving pension plan design: rethinking risk-sharing, The Ambachtsheer Letter, October.

- Andonov, Aleksandar, Rob Bauer en Martijn Cremers (2017), Pension fund asset allocation and liability discount rates, te verschijnen in the Review of Financial Studies.

- Bodie, Zvi, Robert Merton and William Samuelson (1992), Labor supply flexibility and portfolio choice in a life cycle model, Journal of Economic Dynamics and Control, 16: 427-49.

- Bodie, Zvi (1995), On the risk of stocks on the long run, Financial Analysts Journal, 51(3): 18-22.

- Bodie, Zvi en Henriëtte Prast (2012), Rational pensions for irrational people: Behavioral science lessons for the Netherlands, In: The Future of Multi-Pillar Pensions, Lans Bovenberg, Casper van Ewijk en Ed Westerhout (red.), Cambridge University Press, Cambridge.

- Boelaars, Ilja, Lans Bovenberg, Dirk Broeders, Peter Gortzak, Sacha van Hoogdalem, Theo Kocken, Marcel Lever, Theo Nijman en Jan Tamerus (2015), Duurzame vormgeving van het Nederlandse collectieve aanvullende pensioen, Netspar Occasional paper.

- Bovenberg, Lans en Theo Nijman (2014), Persoonlijke pensioenrekeningen met risicodeling, Netspar NEA Paper nr. 56.

- Bovenberg,Lans,Theo Nijmanen BasWerker (2016),Onderzoeksrapport: Projectierentes in verbeterde premieregelingen, Netspar Industry Paper nr. 12.

- Broeders, Dirk, Joanne Kellermann en Olaf Sleijpen (2011), Prudentieel toezicht: Verleden, heden en toekomst, in: René Maatman, Rob Bauer, Danny Bush en Leonard Verburg (red.), Onderneming en Pensioen, Kluwer Deventer: 105-132.

- Broeders, Dirk en Peter Minderhoud (2015), Pensioenvoorziening: Een bouwwerk van vier legoblokken Verzekeringsarchief 1: 9-13.

- Broeders, Dirk, Frank de Jong en Peter Schotman (2016), Interest rate models for pension and insurance regulation, Netspar Design Paper, nr. 56.

- Broeders, Dirk, Damiaan Chen, Peter Minderhoud en Willem Schudel (2016), Pension funds' herding, DNB Working Paper, nr. 503.

- Broeders, Dirk, Arco van Oord en David Rijsbergen (2016), Scale economies in pension fund investments: A dissection of investment costs across asset classes, Journal of International Money and Finance 67: 147-171. 
- Commissie UFR (2013), Advies Commissie UFR, www.rijksoverheid.nl/ documenten/rapporten/2013/10/11/advies-commissie-ufr.

- DNB (2016), Financiële positie pensioenfondsen: Rapportage op verzoek van het Ministerie van Sociale Zaken en Werkgelegenheid, www.rijksoverheid.nl.

- French, Kenneth (2008), Presidential address: The cost of active investing, The Journal of Finance, 63(4): 1537-73.

- Grinold, Richard en Ronald Kahn (2000), Active Porfolio Management, McGraw-Hill, Tweede editie, New York.

- Kocken, Theo (2006), Curious Contracts, Tutein Nolthenius, 's-Hertogenbosch.

- Kocken, Theo en Terry Jones (2014), Boom Bust Boom, http:// boombustclick.com/.

- Mantegna, Rosario en Eugene Stanley (2000), Econophysics: Correlations and Complexity in Finance, Cambridge University Press, Cambridge.

- Merton, Robert C. (2011), Observations on the future of financial innovation and engineering: Addressing financial challenges of the economy, Princeton Lectures in Finance.

- Pelsser, Antoon (2010), Modelonzekerheid en Waardering, Oratie, Maastricht University.

- Tamerus, Jan (2011), Defined Ambition, Eburon, Delft.

- Wachter, Sandra, Brent Mittelstadt en Floridi Luciano (2016), Why a right to explanation of automated decision-making does not exist in the general data protection regulation, beschikbaar op SSRN: https:// ssrn.com/abstract $=2903469$. 
